Preprint version of a chapter published in Hacker, J. S., Hertel-Fernandez, A., Pierson, P., \& Thelen, K. (eds.). American Political Economy: Politics, Markets, and Power. New York: Cambridge University Press, 2021, pp. 270-294. Published version at https://tinyurl.com/nhb4fkc3.

\title{
Asset Manager Capitalism as a Corporate Governance Regime
}

\author{
Benjamin Braun \\ Max Planck Institute for the Study of Societies \\ bb@mpifg.de
}

\begin{abstract}
Who holds power in corporate America? Scholars have invariably answered this question in the language of ownership and control. This paper argues that tackling this question today requires a new language. Whereas the comparative political economy literature has long treated dispersed ownership and weak shareholders as core features of the U.S. political economy, a century-long process of re-concentration has consolidated shareholdings in the hands of a few very large asset management companies. In an historically unprecedented configuration, this emerging asset manager capitalism is dominated by fully diversified shareholders that lack direct economic interest in the performance of individual portfolio companies. The paper compares this new corporate governance regime to its predecessors; reconstructs the history of the growth and consolidation of the asset management sector; and examines the political economy of asset manager capitalism, both at the firm level and at the macroeconomic level.
\end{abstract}

Acknowledgements: Work on this paper began in 2015 and I have since accumulated many debts. Earlier drafts were presented at the Max Planck Institute for the Study of Societies, the Watson Institute at Brown University, the Center for European Studies at Harvard University, and at the Institute for Advanced Study in Princeton. The paper has greatly benefitted from comments by Ruth Aguilera, Lucio Baccaro, Jens Beckert, Gordon Clark, Sahil Dutta, Jan Fichtner, Peter Hall, Lena Lavinas, Perry Mehrling, Suresh Naidu, Herman Mark Schwartz, David Soskice, Cornelia Woll, Nick Ziegler and, especially, the conveners of the 'American Political Economy' project, Jacob Hacker, Alexander HertelFernandez, Paul Pierson, and Kathy Thelen. 


\section{Introduction}

For too long, students of the political economy of corporate governance have been enthralled by the language of ownership and control. This language stems from Berle and Means (1932), who observed that trust-busting policies and the diversification of robber baron fortunes had dispersed stock ownership in the United States, while concentrating corporate control in the hands of a small class of managers. ${ }^{1}$ Jensen and Meckling's (1976) agency theory, while reiterating the notions of shareholder dispersion and weakness, conceptualized shareholders as principals - the only actors with a strong material interest in the economic performance of the corporation. Offering a simple solution to what Berle and Means had considered a complex political problem, agency theory reduced corporate governance to the problem of protecting outside minority shareholders against "expropriation" by insiders, namely corporate managers and workers (La Porta et al. 2000: 4). Notwithstanding the political chasm between these two pairs of authors - New Deal liberals versus pro-market libertarians - the field of corporate governance melded these ideas into a single Berle-Means-Jensen-Meckling (BM-JM) ontology - the United States as a society in which shareholders, while dispersed and weak, are the owners and principals of the corporation. This ontology underpins 'shareholder primacy' (or 'shareholder value'), which in the late $20^{\text {th }}$ century emerged as the dominant corporate governance regime. This regime was geared towards three goals - ensuring a market for corporate control, allowing shareholders to monitor managerial performance, and aligning the material interests of managers with those of shareholders (Fourcade \& Khurana 2017: 355). So complete was its victory that two prominent legal scholars announced the "[t]he triumph of the shareholder-oriented model of the corporation" and the "end of history for corporate law" (Hansmann \& Kraakman 2001: 468).

When history resumed its course, it wrong-footed many students of corporate governance. Comparative political economy (CPE) scholars, while adding important institutional detail, have largely taken the BM-JM ontology for granted, assuming

\footnotetext{
${ }^{1}$ Among others, Marx (1981[1894]), Hilferding (1985 [1910]), and Veblen (1923) had already written extensively about the relationship between finance capital and corporate ownership and control.
} 
dispersed, weak (and impatient) shareholder-principals (Roe 1994; Hall \& Soskice 2001; Aguilera \& Jackson 2003; Gourevitch \& Shinn 2005). ${ }^{2}$ Since Hansmann and Kraakman's (and Hall and Soskice's) writing, however, the re-concentration of U.S. stock ownership has dramatically accelerated (Fichtner et al. 2017). Today, three asset managers - Vanguard, BlackRock, and State Street Global Advisors - together hold more than 20 per cent of the shares of the average S\&P 500 company (Backus et al. 2020: 19). Today, the investment chain is dominated by for-profit asset management firms rather than by the pension funds that shaped the CPE literature's perception of the shareholder primacy regime (see Figure 1). While 'asset manager' comprises 'alternative' asset managers - namely, hedge, private equity, and venture capital funds - the bulk of capital is invested via mutual funds and exchange-traded traded funds, which are the focus of this chapter. ${ }^{3}$ My central argument is that this new 'asset manager capitalism' constitutes a distinct corporate governance regime.

Figure 1: The equity investment chain

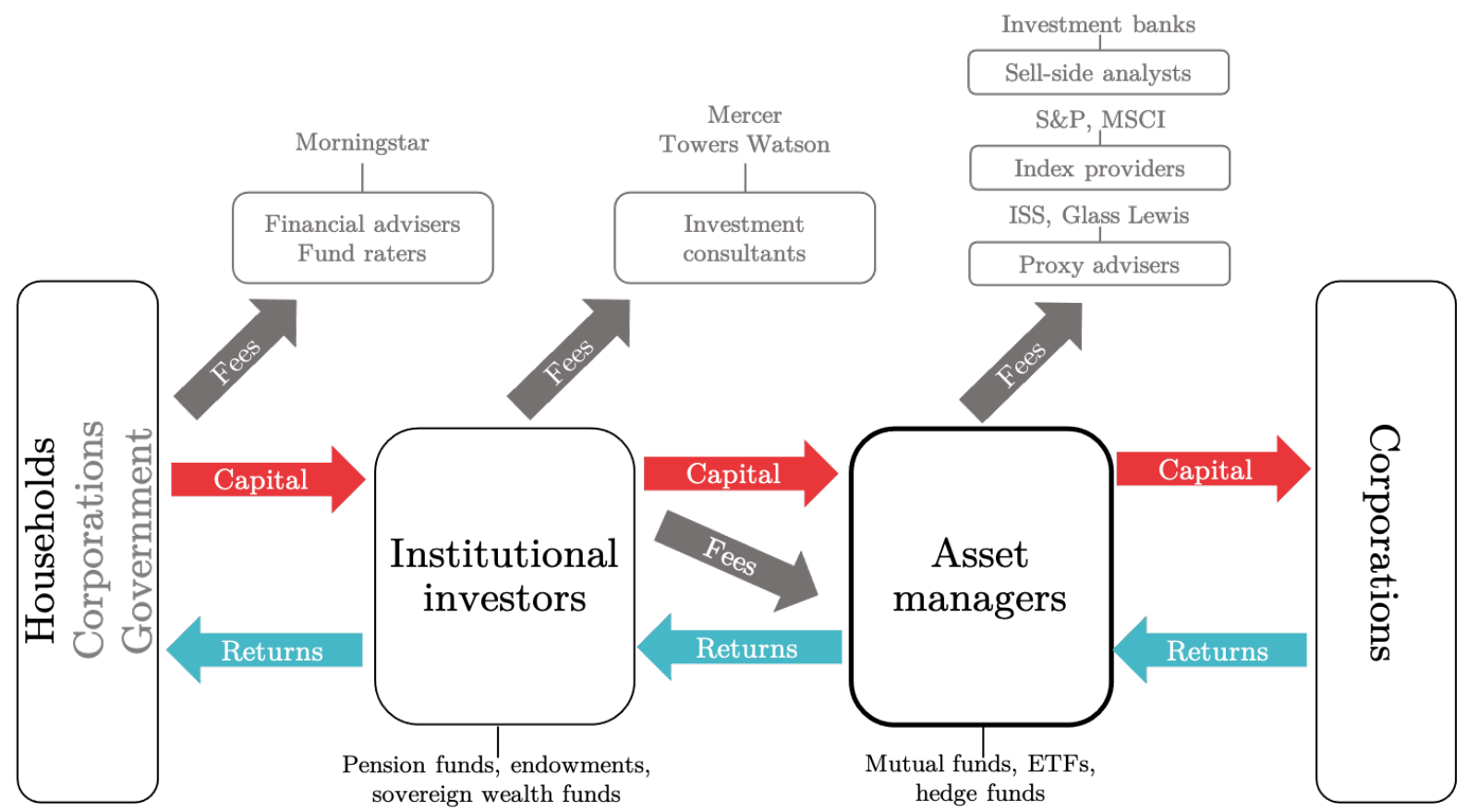

Source: Author's own illustration.

\footnotetext{
${ }^{2}$ For a notable exception, see Davis (2008).

${ }^{3}$ Private equity and venture capital funds are also excluded by this paper's focus on holdings in listed companies.
} 
Four hallmarks characterize this new corporate governance regime. First, U.S. stock ownership is concentrated in the hands of giant asset managers. Second, due to the size of their stakes, asset managers are, in principle, strong shareholders with considerable control over corporate management. While this divergence from 'dispersed and weak' alone would require corporate governance scholars to rekindle their conceptual toolkit, two additional features distinguish asset manager capitalism from previous corporate governance regimes. The third hallmark is that large asset managers are "universal owners" that hold fully diversified portfolios (Hawley \& Williams 2000). Finally, as for-profit intermediaries with a fee-based business model, asset managers hold no direct economic interest in their portfolio companies. Whereas under the shareholder primacy regime the dominant shareholders sought to maximize the stock market value of specific firms, under asset manager capitalism the dominant shareholders are incentivized to maximize their assets under management. Clearly, the BM-JM ontology does not map onto this new landscape (Gilson \& Gordon 2013).

The paper is organized as follows. The next section gives a big-picture overview of the evolution of U.S. stock ownership and corporate governance regimes. Section 3 traces the policies and economic developments behind the growth of the asset management sector since the Revenue Act of 1936. Section 4 takes a critical look at the promise of universal ownership and at assets managers' economic interests. Section 5 zooms in on the economic and political power of asset managers at the firm, sectoral, and macroeconomic levels, with a focus on the relationship between asset manager capitalism and inequality. The conclusion highlights broader implications for corporate governance studies and comparative political economy.

\section{Corporate governance regimes in historical perspective}

The comparative political economy and corporate finance literatures used to consider it "one of the best established stylized facts" that "ownership of large listed companies is dispersed [...] in the U.S. and concentrated in most other countries" (Franks et al. 2008: 4009). This stylized fact does not hold anymore. Charting the historical development of U.S. stock ownership concentration no longer yields an L-shaped curve, but a U-shaped one. A period of high-concentration in the late $19^{\text {th }}$ century gave way 
to a period of highly dispersed share ownership in the mid- $20^{\text {th }}$ century, which has been followed by a long (and ongoing) period of re-concentration. The condensed overview presented in this section and summarized in Table 1 compares four successive corporate governance regimes across four shareholder-related dimensions. Preparing the ground for the discussion of macro-level implications in section 5, the periodization also relates corporate governance regimes to each period's growth regime. ${ }^{4}$

Table 1: Hallmarks of historical corporate governance regimes

\begin{tabular}{|c|c|c|c|c|}
\hline Main shareholders & Robber barons & Households & Pension funds & Asset managers \\
\hline $\begin{array}{l}\text { Concentration of } \\
\text { ownership }\end{array}$ & High & Low & Medium & High \\
\hline $\begin{array}{l}\text { Control of } \\
\text { shareholders }\end{array}$ & Strong & $\begin{array}{l}\text { Weak: } \\
\text { exit }\end{array}$ & $\begin{array}{l}\text { Medium: } \\
\text { exit or voice }\end{array}$ & $\begin{array}{l}\text { Potentially strong: } \\
\text { voice, no exit }\end{array}$ \\
\hline $\begin{array}{l}\text { Portfolio } \\
\quad \text { diversification }\end{array}$ & Low & Low & Medium & High (indexed) \\
\hline Interest in firms & High & High & Medium & Low \\
\hline Corp Gov Regime & $\begin{array}{l}\text { Finance } \\
\text { capitalism }\end{array}$ & Managerialism & $\begin{array}{l}\text { Shareholder } \\
\text { primacy }\end{array}$ & $\begin{array}{l}\text { Asset manager } \\
\text { capitalism }\end{array}$ \\
\hline Growth Regime & $\begin{array}{l}\text { Monopoly } \\
\text { capitalism }\end{array}$ & Fordism & $\begin{array}{l}\text { Privatized } \\
\text { Keynesianism }\end{array}$ & $\begin{array}{l}\text { Asset manager } \\
\text { capitalism }\end{array}$ \\
\hline
\end{tabular}

By the end of the 19th century, corporate America was largely owned and controlled by a handful of corporations and banks, in turn owned and controlled by the "blockholder oligarchy" formed by figures such as J.P. Morgan, Andrew Carnegie, and John D. Rockefeller (Gourevitch \& Shinn 2005: 244). Best captured by Hilferding's (1985 [1910]) concept of "finance capitalism", this corporate governance regime was characterized by concentrated stock ownership and strong control, exercised directly by owner-managers or indirectly via financial conglomerates. The latter's portfolios were undiversified, giving them a strong stake in the fortunes of their corporate

\footnotetext{
4 "Growth regime" is used here in the tradition of "modes of regulation" (Aglietta 1979) and "regimes of accumulation" (Kotz et al. 1994), both of which comprise more than corporate governance arrangements.
} 
empires. ${ }^{5}$ The investment-led growth regime of the period is best captured by the concept of "monopoly capitalism" (Baran \& Sweezy 1966).

Several factors contributed to the dissolution of the concentrated ownership structure of the Gilded Age, including Progressive Era anti-trust laws, war-related federal taxes forcing robber barons to sell shares for cash, and the stock market boom of the 1920s, which turned millions into stockholders (Ott 2011). By 1945, households held 94 per cent of U.S. corporate equity (Figure 2 below). ${ }^{6}$ The weakness of these dispersed shareholders concentrated power in the hands of the managers of increasingly large corporations, giving rise to the corporate governance regime of "managerialism" (Chandler 1977). At the macro-level managerialism, strong trade unions, Keynesian macroeconomic management, and the Bretton Woods system coalesced into the growth regime of "Fordism" (Aglietta 1979).

Whereas stock ownership concentration in the late $19^{\text {th }}$ century was propelled by industrial monopolization, the main drivers of concentration in the $20^{\text {th }}$ and $21^{\text {st }}$ centuries were developments within the investment chain. The first development was the emergence and growth of capital-pooling institutional investors, notably pension funds, whose direct equity holdings reached an all-time high of 27 per cent in 1985 (Figure 2). While the investor configuration was dubbed "investor capitalism" (Useem 1996) or "pension fund capitalism" (Clark 2000), the corporate governance regime it gave rise to was shareholder primacy (Lazonick \& O'Sullivan 2000). ${ }^{7}$ Its hallmarks were moderately dispersed stock ownership; institutional investors large enough to be heard (voice) yet small enough for ownership stakes to be liquid (exit); and moderately diversified not-for-profit institutional investors, who retained enough 'skin in the game' to take a strong interest in their portfolio companies. At the macro level, shareholder

\footnotetext{
${ }^{5}$ Gourevitch and Shinn (2005: 243) note that this "blockholder trust model ... made the United States look rather like Germany at the turn of the last century". What Morgan and Carnegie were to the former, Deutsche Bank and Allianz were to the latter (Windolf \& Beyer 1996).

${ }^{6}$ This dispersion was never even across the wealth distribution. U.S. share ownership was, and is, concentrated at the top (Figure 5 below).

${ }^{7}$ For the argument that financial logics had penetrated managerial corporate governance already in the 1960s, see Knafo and Dutta (2020).
} 
primacy co-evolved with the debt-led growth regime of "privatized Keynesianism" (Boyer 2000; Crouch 2009).

The investment chain lengthened a second time when, starting in the 1980s, institutional investors began to delegate to for-profit asset managers. ${ }^{8}$ Along the four dimensions that define the corporate governance regime, asset manager capitalism diverges starkly from shareholder primacy: stock ownership is concentrated in the hands of a few giant asset managers; the latter hold large minority stakes despite being fully diversified; and their interest in the economic performance of individual portfolio firms is weak.

At the macro-level, the parallel increase in market concentration, which is particularly pronounced in the U.S. (Philippon 2019), makes it tempting to diagnose a $21^{\text {st }}$ version of the finance capitalism-monopoly capitalism configuration. While it is too early to define macro-level correlates, it is worth noting that no separate term may be needed to describe the current growth regime. The core feature of this regime would be "asset dominance" - the idea that asset prices, rather than wages, drive investment and consumption, and therefore become the chief targets of macroeconomic policy (Ansell 2012: 533; Chwieroth \& Walter 2019; Adkins et al. 2020; Christophers 2020). I will return to the macro implications of asset manager capitalism in section 5 .

\section{The Great Re-Concentration}

Mark Roe (1994) has explained the policies sustaining dispersed ownership as the result of Americans' deep-seated opposition to concentrated economic or political power. From this perspective, asset manager capitalism constitutes as puzzle. By contrast, Hilferding (1985 [1910]) and Marxist scholars in the regulationist and social-structuresof-accumulation traditions have long argued that capitalist accumulation has a builtin tendency towards greater concentration, and that mature capitalist accumulation exerts a strong pressure on finance capital to concentrate over time (Aglietta 1979;

\footnotetext{
8 'Asset manager' here refers to pure asset management firms such as BlackRock (publicly listed) and Vanguard (mutually owned by the shareholders of its funds), as well as to the asset management arms of insurers (such as Allianz) and of banks (such as J.P. Morgan Chase).
} 
Kotz, McDonough \& Reich 1994). From this perspective, the Berle and Means world was the anomaly and the 'Great Re-Concentration' - a seven-decade period during which shareholdings shifted from households to pension funds and, more recently, to asset management companies (see Figure 2) - was overdetermined. Even if that were the case, however, we would still need to identify the specific policies and developments that enabled the Great Re-Concentration, which I will attempt in the remainder of this section. During a first phase (1936-2000), tax rules for mutual funds, retirement legislation, and financial regulation fed the growth of the asset management sector. Since 2000, the dominant dynamic has been concentration within the asset management sector.

Figure 2: The structure of U.S. corporate equity ownership, 1945-2020

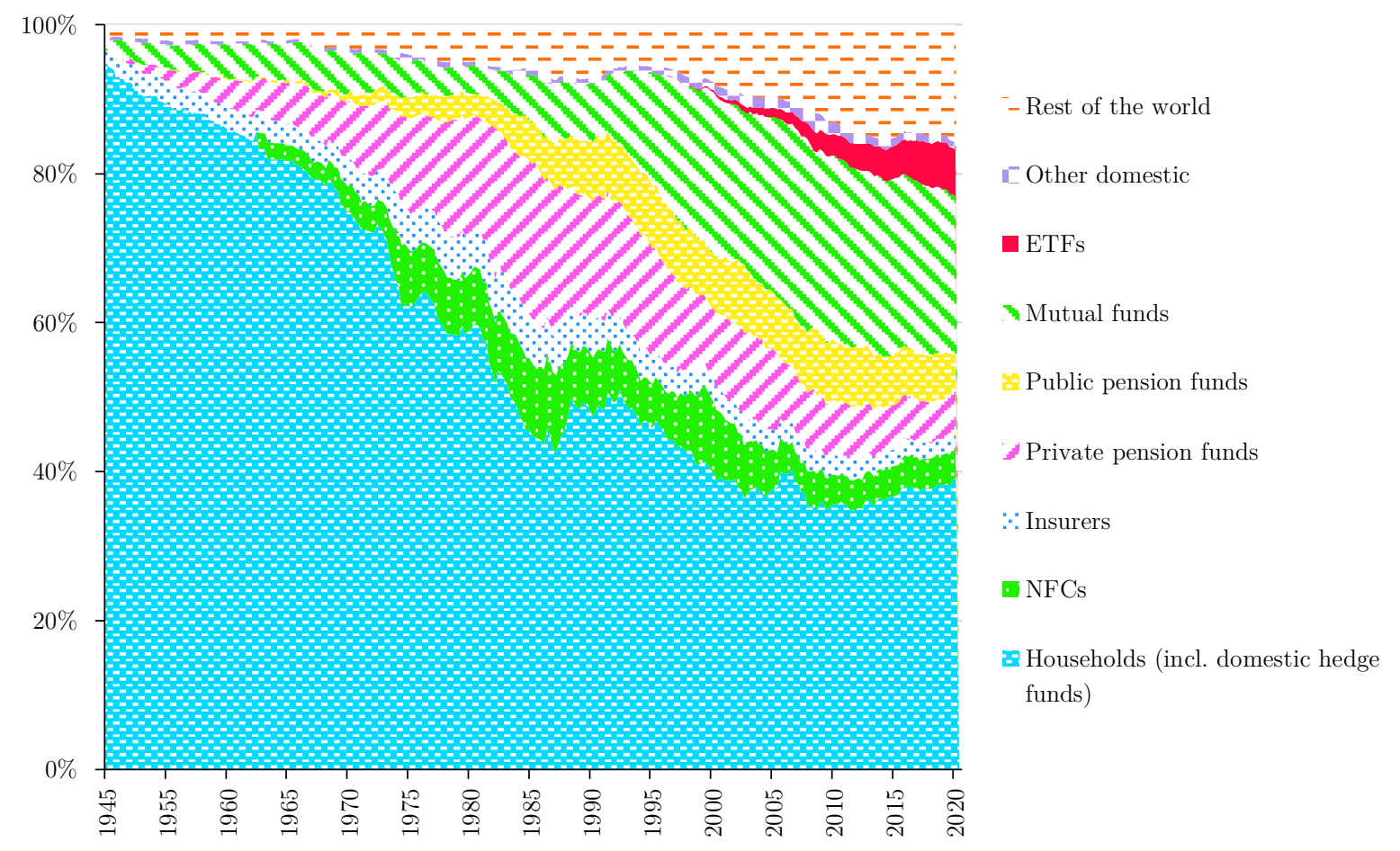

Source: Financial accounts of the United States (Z.1).

Note on types of equity: The data comprises equity issued by U.S.-listed foreign corporations (21 per cent of the total) and closely held equity (15 per cent of the remaining domestic equity). The total dollar value of U.S. corporate equity by year-end 2019 was USD 55 trillion.

Note on holders of equity: The recent expansion of the categories 'rest of the world' and 'households' hides the growth of private equity funds and hedge funds. (1) Closely held equity has increasingly become dominated by private equity funds, subsumed here under 'households'. By a rough estimate, private equity funds hold 2-3 per cent of U.S. corporate equity. (2) Hedge fund holdings (roughly 10 per cent of listed shares) are displayed as assets of households (for domestic hedge funds) or of the rest of the world (for foreign hedge funds, including U.S. funds registered in offshore jurisdictions) (see www.federalreserve.gov/releases/Z1/z1_technical_qa.htm). 
Between the end of World War II and the turn of the $20^{\text {th }}$ century, the share of corporate equity held directly by households declined steadily, falling below 40 per cent after the bursting of the dotcom bubble in 2000. This decline was the flipside of the pooling of savings via collective investment vehicles, which increased their share of equity holdings from virtually zero in 1945 to 42 per cent in 2000.

The big picture can be read off Figure 3. Total mutual fund assets (solid black line) have grown in lockstep with retirement assets since 1984. That growth accelerated when defined contribution (DC) plan and individual retirement account (IRA) assets took off in the mid-1990s. The share of retirement assets in total mutual fund assets doubled over the course of the 1990s, from 20 to 40 per cent (dotted red line). This share has recently plateaued at 45 per cent, whereas mutual fund assets have continued to rise, indicating the growing importance of (non-retirement) household savings as well as foreign investment in U.S. mutual fund shares.

Figure 3: Retirement assets and their share of mutual fund assets, 1974-2020

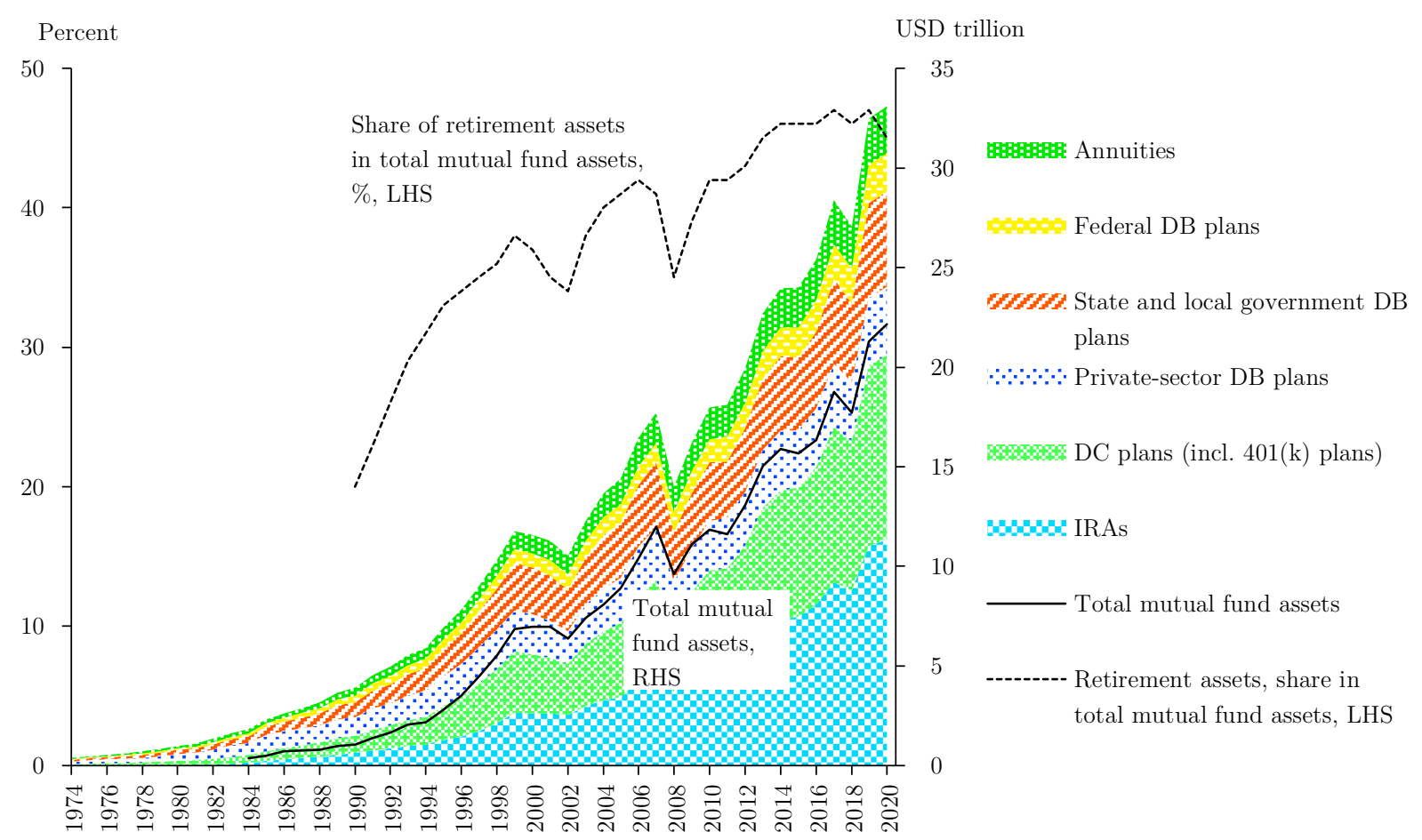

Source: Investment Company Institute. 
The explosive growth of mutual fund assets was not preordained. Mutual funds are legal constructs built, over a long period, on regulatory statutes and on various pieces of tax and retirement legislation. The first such piece was the Revenue Act of 1936, which allowed mutual funds to pass dividends on to investors untaxed, thus ensuring that fund shareholders were not disadvantaged vis-à-vis direct stock investors (Fink 2008: 28). Congress made this tax privilege conditional on mutual funds owning no more than 10 per cent of the voting stock of any corporation, with the explicit goal of preventing them from acquiring controlling stakes (Fink 2008: 28). Today, the tax exemption lives on in the Internal Revenue Code (Coates 2009: 596). ${ }^{9}$

Fund size continued to be key issue in the run-up to the Investment Company Act of 1940. While mutual funds supported the idea of legislation, they opposed certain provisions in the original bill drafted by the Securities and Exchange Commission (SEC). Arguing that investment companies selling securities into a falling market had been one of the sources of the 1929 crash and seeking to avoid such "runs" on mutual funds in the future, the SEC was proposing to limit their size to USD 150 million. The mutual fund lobby strongly opposed the size limitation and, rejecting the bank run analogy, succeeded in keeping it out the final version of the bill (Fink 2008: 39). Section 14(b) of the Investment Company Act, which authorized the SEC to reexamine future increases in fund size, was never activated.

The Revenue Act and the Investment Company Act established the legal foundation for the existence of mutual funds without, however, doing much to feed their business. ${ }^{10}$ The tide of retirement assets that eventually flooded the asset management sector was the cumulative effect of four subsequent pieces of retirement legislation: Taft-Hartley (1947), ERISA (1974), the 401(k) provision (1978), and universal IRAs (1981). Long before Peter Drucker warned of "pension fund socialism" coming to America (Drucker 1976), the anti-labor Taft-Hartley Act of 1947 prohibited employers from contributing

\footnotetext{
${ }^{9}$ This rule applies at the level of the individual fund. Breaches of this threshold by fund families - an imminent scenario for BlackRock or Vanguard - thus fall within the letter of the 1936 law but may conflict with its spirit.

${ }^{10}$ Defined benefit plans, which then did not invest in mutual funds, prevailed in the corporate retirement market, while the small market for defined contribution plans was dominated by banks and insurers (Fink 2008: 113).
} 
to union-controlled pension funds (McCarthy 2017: 95-100). The Employment Retirement Income Security Act (ERISA) of 1974, which brought the riskiness of private pension promises - hitherto negotiated between employers, unions, and employees - under federal government regulation (Wooten 2004: 3), further weakened labor control over the investment of retirement assets. It did so by tightening a fiduciary requirement originally introduced by Taft-Hartley. In 1979, the Department of Labor specified that prudence was a matter not of individual securities but of portfolio construction, thus tying fiduciary duty to the prescriptions of modern portfolio theory (Montagne 2013: 53). By narrowing the prudent person rule down to best practice as it prevailed in the financial sector, ERISA created a strong incentive for retirement plan managers to share fiduciary responsibility with professional, external asset managers (Clark \& Monk 2017; van der Zwan 2017).

For all of the mutual fund industry's legislative victories, its growth had stalled amidst the 1970s bear market (Clowes 2000: 192). Growth resumed in a big way with the addition of section 401(k) to the Internal Revenue Code in 1978 and the Economic Recovery Tax Act of 1981. Although the mutual fund industry had not lobbied for the 401(k) provision - the DC-plan implications of which were 'discovered' only in 1980 by Ted Benna, and confirmed by the IRS in 1981 (Hacker 2019: 110) - it proved a godsend for the industry. In contrast to the "mostly inadvertent" birth of the 401(k) provision (ibid.), the "universal IRA" - which allowed annual tax-deductible IRA contributions of up to USD 2000 - had been invented by, and lobbied for, the Investment Company Institute (Fink 2008: 125). In the 1980s, IRA and DC assets became the fastest-growing segments of the retirement market, and today account for two thirds of all retirement assets, and for an even larger share of retirement assets invested in mutual fund and ETF shares.

By the year 2000, a series of tax rules, retirement laws, and financial regulations had helped create a USD 7 trillion mutual fund sector that managed USD 2.6 trillion of retirement assets (Figure 3). The dominant shareholders, however, were still the public pension funds, which campaigned aggressively for the corporate governance reforms that institutionalized the shareholder primacy regime, including independent directors, destaggered boards, and proxy voting (Davis \& Thompson 1994; Webber 2018: 45-78). 
However, even the largest holdings of the largest public pension funds barely reached 1 per cent of a corporation's market capitalization in the 1990s. Dispersed share ownership thus remained a hallmark of pension fund capitalism.

Consolidation within the asset management sector, 2000 - present

The aggregate stock ownership data in Figure 2 suggests that little has changed over the last twenty years, bar a modest expansion of foreign ownership, continued growth of mutual funds, and the emergence and growth of exchange-traded funds. This continued growth of the overall asset management sector cannot, however, explain the jump in the largest asset managers' average ownership stakes from 1 per cent in the 1990s to almost 10 per cent today. Indeed, in contrast to the slow growth of the underlying asset pool in the late $20^{\text {th }}$ century, the crucial dynamic in the $21^{\text {st }}$ century has been concentration within the asset management sector.

At present, this concentration is uneven. The overall asset management sector remains relatively fragmented, and observers expect mergers and acquisitions to further accelerate and bring higher future concentration (Flood 2020). Already, following a decade of increasing consolidation, the largest one per cent of asset managers today control 61 per cent of the assets managed by the sector (Riding 2020). At the very top, the dominance of the Big Three is the result of their cornering the now highly concentrated ETF market - BlackRock (39\%), Vanguard (25\%) and SSGA (16\%) control a combined market share of 80 per cent (Kim 2019).

While the contingency of the 2008 financial crisis played an important role, concentration in the financial sector has been driven by some of the same forces as concentration in labor and product markets (Ansell \& Gingrich forthc.; Naidu forthc.; Rahman \& Thelen forthc.; Schwartz forthc.). Although asset managers compete on performance and cost, the cost of investing via for-profit asset managers is high. Between 1980 and 2007, asset management revenues (mutual, money market, and exchange-traded funds) quintupled from about 0.2 per cent to just under 1 per cent of GDP (Greenwood \& Scharfstein 2013: 9). Casting a bright light on remuneration in the financial sector generally, the financial crisis of 2008 accelerated the shift from 
expensive active funds into low-cost index funds, which had been underway since the early 1990s (Figure 4) (Braun 2016; Petry et al. 2021). The cost difference between active equity funds and index equity funds (traditional and ETFs) is significant, and has increased over time. The expense ratio of active funds was four times higher than that of index funds in 2000 and is nearly ten times higher today (Figure 4). In the United States, this cost advantage has been reinforced by a tax loophole for ETFs (Poterba \& Shoven 2002). In addition, the financial crisis dealt a heavy blow to the banking sector. While asset managers generally benefitted from distrustful investors moving money out of the banking sector, BlackRock in particular gained from its June 2009 acquisition of the asset management arm of Barclays, which included iShares, then the world's leading ETF brand (Mooney \& Smith 2019).

Figure 4: Domestic active equity funds versus domestic index equity funds (incl. ETFs), relative market share (1993-2019) and expense ratios (2000-2019)

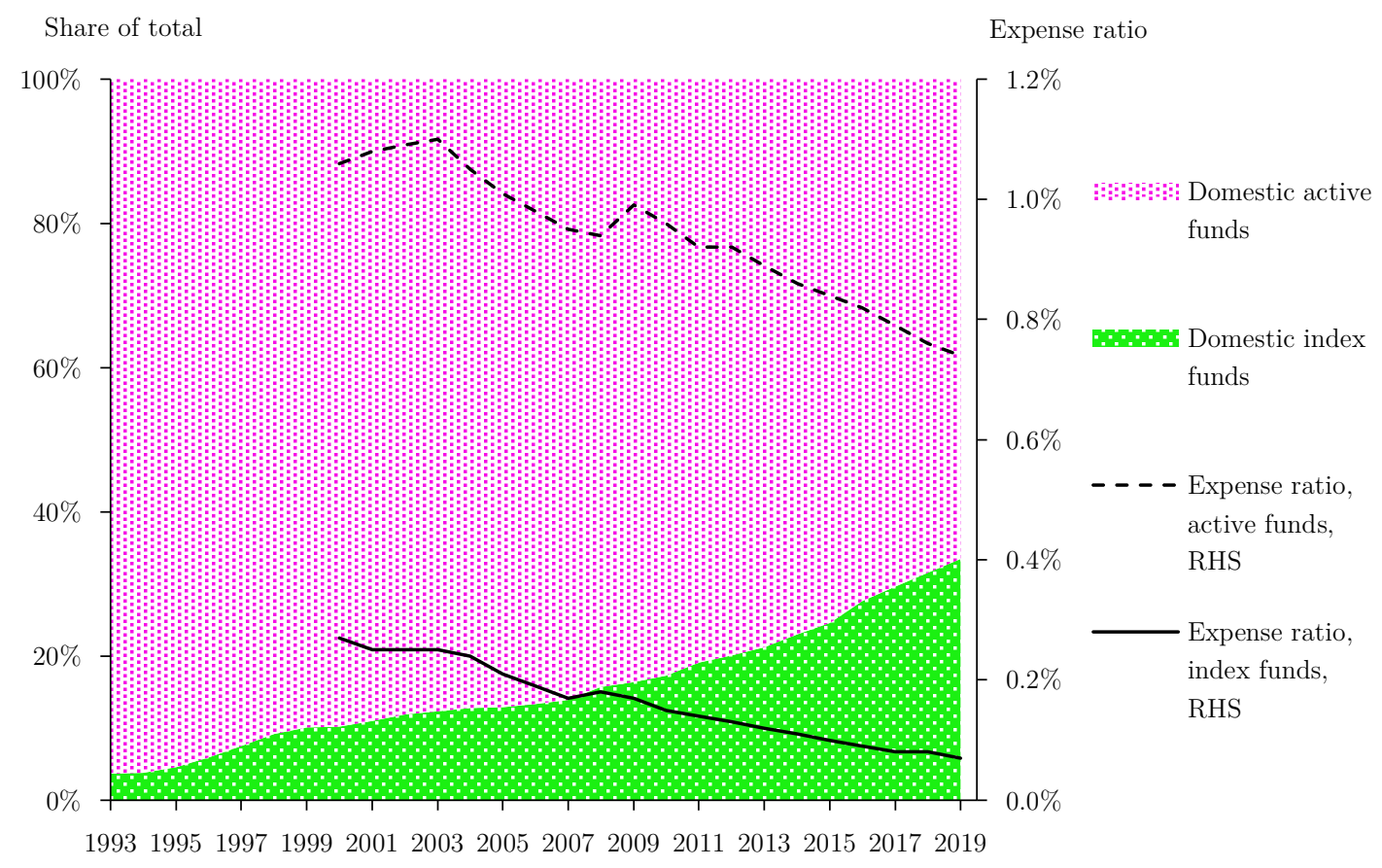

Source: Investment Company Institute.

Note: Expense ratios are asset-weighted averages. 
If the contingency of the financial crisis made investors more cost-sensitive, structural forces have helped translate that focus on cost into accelerated concentration. While intellectual property rights have become more important for financial sector firms in general (Schwartz 2017), asset management in particular resembles digital platform industries, where network effects and scale economies drive monopolization (Srnicek 2017; Rahman \& Thelen 2019). ${ }^{11}$ Three elements underpin the "almost unlimited scale economies" of "asset management platforms" (Haberly et al. 2019: 169). First, the fixed cost structure of ETFs - an expensive infrastructure on the back-end, combined with constant marginal costs - creates conventional scale economies. ${ }^{12}$ Second, unlike active mutual funds, whose transaction costs tend to increase beyond a certain size threshold, ETFs benefit from network effects - more investors make the shares of an ETF more liquid. Third, asset management companies have increasingly benefitted from data-based returns to scale. This trend is epitomized by BlackRock's Aladdin, a risk-management system so widely used in the asset management industry that BlackRock's CEO has described it as "the Android of finance" (Haberly et al. 2019: 172). Even BlackRock's immediate rivals use Aladdin (Zetzsche et al. 2020: 290). In sum, capturing the ETF market and exploiting economies of scale has made the Big Three the largest asset managers in the world. (How) do these firms wield their new power?

\footnotetext{
${ }^{11}$ Exchanges and index providers - key components of the infrastructure of asset management - display similar dynamics, and even higher concentration (Petry, Fichtner \& Heemskerk 2021; Petry 2020).

12 The SEC recently changed the rules governing the share creation and redemption mechanism at the heart of ETFs in an explicit attempt to lower barriers to entry and enhance competition (SEC 2019: 197-98).
} 


\section{Diversified and disinterested}

Besides stock ownership dispersion, asset manager capitalism also undercuts two further tenets of the BM-JM ontology, namely that institutional investors are speculators making targeted bets and that their primary economic interest is in the performance of their portfolio firms.

\section{Diversified: The promise of universal ownership}

Political economists have long equated LME-type institutional investors (a catch-all category comprising both pension funds and mutual funds) with 'impatient' capital, in contrast to the 'patient' capital provided by banks and other strategic blockholders in coordinated market economies (Hall \& Soskice 2001; Höpner 2003; Culpepper 2005; Goyer 2011). ${ }^{13}$ Concentration and the rise of indexing, however, have effectively eliminated 'exit' as an option for the largest asset managers (Jahnke 2019). This scenario was not anticipated. In a clear-eyed survey of the changing U.S. shareholder landscape, Davis still highlighted a "surprising combination of concentration and liquidity" as the core features of what he termed - referencing Hilferding - the "new finance capitalism" (Davis 2008: 20, my emphasis). Analyzing data up to 2005, in which index fund providers such as Vanguard did not yet appear as blockholders with multiple stakes above 5 per cent, Davis noted that index funds "typically end up with smaller ownership positions in a larger number of companies" (ibid.: 15). By the time Davis' article was published, BlackRock's average S\&P 500 shareholding had already surpassed the 5 per cent threshold. Vanguard followed in 2012 and today holds an average stake of 9 per cent (Backus, Conlon \& Sinkinson 2020: 19). This was a watershed moment - full diversification and large blockholdings ceased to be mutually exclusive.

Today, large asset management companies are quintessential "universal owners" (Monks \& Minow 1995; Hawley \& Williams 2000). The promise associated with this concept is enormous. As holders of the market portfolio, universal owners should, in principle, internalize all externalities arising from the conduct of individual portfolio

\footnotetext{
${ }^{13}$ For notable exceptions, see Dixon (2012) and Deeg and Hardie (2016).
} 
companies (Condon 2020). The concept of the universal owner conjures the image of a utilitarian social planner curbing economic activities - above all: carbon emissions - whose aggregate monetary cost exceeds their aggregate monetary value (Azar et al. 2020). While the concept is not new, it has become more compelling in that the growth of index funds and ETFs has deprived the largest universal owners of the option of exit (reinforcing the internalization of externalities), while the size of their blockholdings affords them considerable power through voice (Jahnke 2019; Fichtner \& Heemskerk 2020). ${ }^{14}$ Besides carbon emissions, asset managers calling on pharma companies to set competition aside and cooperate in the search for a Covid-19 vaccine offers a striking example of universal ownership in action (Mooney \& Mancini 2020). The example also illustrates the close link - and slippery conceptual slope - between externality-reducing universal ownership and competition-reducing common ownership (see section 5 ).

The Big Three have been quick to harness the promise of universal ownership to shape their public image as long-term shareholders whose interests are fundamentally aligned with environmental, social, and governance (ESG) sustainability. BlackRock CEO's Larry Fink's annual letters to CEOs and to investors exemplify this rhetoric (Condon 2020: 54), which seeks to replace shareholder value as the dominant corporate governance ideology with a 'stewardship' model. Whereas the shareholder value regime made good corporate governance a matter of corporate accountability to shareholders, in recent years the latter - i.e., asset managers - have themselves faced demands for accountability from their principals. The global spread of stewardship codes illustrates this ideological and regulatory shift (Hill 2017). Investors increasingly expect asset managers to act as stewards of their capital in ways that go beyond maximizing shortterm returns, above all in the context of global warming (Christophers 2019). In theory, the logic of universal ownership is compelling. In practice, it is counteracted by the causes of diversification - indexing and size - and by the economic incentives faced by asset managers.

\footnotetext{
${ }^{14}$ Capital invested via index funds is "steered" not by individual fund managers but by index providers such as MSCI or S\&P, which often exercise considerable discretionary power (Petry, Fichtner \& Heemskerk 2021).
} 


\section{Disinterested: The separation of legal and economic ownership}

Perhaps the most destructive effect of the BM-JM ontology has been the notion that shareholders 'own' the corporation. In large part due to the work of Lynn Stout (2012), it is increasingly recognized that U.S. corporate law does not actually assign ownership rights to shareholders (see also, Ciepley 2013). ${ }^{15}$ Asset manager capitalism has added an important twist to this - the separation of the legal ownership of a stock from the economic interest in the return from that stock.

Berle and Means' (1932: 119) defined ownership as "having interests in an enterprise" and control as "having power over it". The separation of the two, they noted, reduced "the position of the owner ... to that of having a set of legal and factual interests in the enterprise" (ibid.). Agency theorists sought to re-unite ownership and control by strengthening shareholder protection and by aligning the incentives of managers with those of shareholders (Jensen \& Meckling 1976). Indeed, giving managers "interests in the enterprise" via stock options and other forms of incentive pay during the 1990s merged the interests - and, by implication, the class position - of the two groups, strengthening shareholder control at the expense of labor (Boyer 2005; Goldstein 2012). Since Jensen and Meckling, the concentration of stock ownership has further increased shareholder power, thus seemingly perfecting the re-unification of ownership and control. The rise of asset management companies, however, has perfected a different separation - that between the "legal interest" and the "factual interest" in the enterprise. Indeed, the separation of ownership and control has been joined by the "separation of ownership from ownership" (Strine Jr 2007: 7; cf. Gilson \& Gordon 2013).

Agency theory rests on the assumption that shareholders have more 'skin in the game' than managers or workers (Fama \& Jensen 1983: 301). While that was always questionable, what agency theorists ignored entirely is the shareholder without any skin in the game at all - one that holds the legal title (shares and the attached voting rights) but not the economic interest. Today, the dominant shareholders are

\footnotetext{
${ }^{15}$ Hence the use of 'stock ownership' rather than 'corporate ownership' in the present paper.
} 
'disinterested' in this way. While mutual funds and ETFs legally own stocks, they pass on any returns to the fund's investors, the ultimate 'asset owners' (retail or institutional investors) ${ }^{16}$ For revenue, asset managers rely on fees. Unlike alternative investment vehicles such as hedge funds, whose fee structure usually includes a large performance-based component, mutual funds and ETFs typically charge their investors fees that amount to a fixed percentage of the assets invested (this 'expense ratio' is displayed in Figure 4 above).

The economic interests of asset managers thus are different from the economic interests ascribed to shareholders in the BM-JM ontology. Simply put, asset managers are incentivized to maximize assets under management. For actively managed funds, adequate relative returns matter, but only to the extent that they cause clients to switch to competitors. For indexed funds, the return equals the benchmark return (minus a 'tracking error' that index funds seek to minimize), which eliminates even the indirect nexus between returns and revenue.

From an agency theory perspective, the implications of this "double-agency society" a phrase coined by the late founder of Vanguard (Bogle 2012: 29) - are analogous to the separation of ownership and control. ${ }^{17}$ Asset owners (the principal) hiring asset managers (the agent) must fear that the latter's incentives are not aligned with their interests. In the standard investment chain configuration, this agency problem repeats itself at least once, between the asset owner (a pension fund) and the ultimate beneficiaries (the plan members). Thus, the supposed principals in the shareholdermanager relationship are themselves agents to a chain of principals, namely asset owners and ultimate beneficiaries (Kay 2012; Arjaliès et al. 2017; Bebchuk et al. 2017; Clark \& Monk 2017). The result of this proliferation of agency relationships is a proliferation of conflicts of interest.

\footnotetext{
${ }^{16}$ On hedge fund strategies to disentangle legal ownership from the risk of the underlying asset, see Ringe (2016).

${ }^{17}$ See also Gilson and Gordon (2013) on "agency capitalism." The spread of outsourcing and franchising (Weil 2014; Schwartz forthc.) points to the proliferation of agency relationships also on the production side. In the platform economy especially, economic activity is coordinated via arms-length, market-based relationships rather than direct control.
} 


\section{The political economy of asset manager capitalism}

Shareholder primacy refers to a corporate governance regime under which the interests of institutional investors - in close alliance with corporate managers - dominated over those of workers and society at large. While this power imbalance may well persist, the most powerful actors in the equity investment chain are no longer institutional asset owners but their agents, the asset managers. From a Hilferdingian perspective, the concentration of finance capital should strengthen the structural power of asset owners, by facilitating coordination among fewer and more homogenous agents. ${ }^{18} \mathrm{At}$ the same time, however, the interests of asset owners are not necessarily aligned with those of asset managers. This section discusses the political economy of asset manager capitalism at the firm, sectoral, and macroeconomic levels.

\section{Firm level: The cost of engagement}

In the BM-JM ontology, shareholders as principals have a vital interest in the performance of their portfolio companies, which they therefore monitor closely. U.S. securities and corporate law, however, has always sought to limit the role of large shareholders in corporate governance (Roe 1994: 102), as illustrated by the ongoing conflict between the SEC and business groups over proxy access rules (Rahman \& Thelen forthc.). By contrast, under asset manager capitalism, the issue has shifted from too much engagement to too little engagement.

Monitoring and engaging with portfolio companies is costly, and asset managers do not directly benefit from the returns to such stewardship activities (Coffee 1991). Some argue that competition solves this problem - investors increasingly demand stewardship services from their asset managers, and failure to monitor and engage with firms diminishes returns, driving investors away (Fisch et al. 2019; Jahnke 2019). For index funds, this is doubtful from a purely theoretical perspective - any performance gains they achieve by engaging with a specific company are reaped disproportionately by active funds with bets on that specific company (Lund 2017). Recent empirical

\footnotetext{
${ }^{18}$ Note that asset managers are merely the most visible agents in a sprawling "wealth defense industry" (Winters 2017; Ajdacic et al. 2020).
} 
work suggests that index funds are less likely than other funds to engage with portfolio firms (Heath et al. 2021), even on negative externalities that universal owners should, in theory, seek to curb (Briere et al. 2019). ${ }^{19}$

The problem of the direct cost of engagement is exacerbated by the indirect cost of alienating corporate managers - portfolio firms are often also clients of asset managers. As a consequence, the asset management arms of large banks, for instance, tilt their equity investments towards the clients of their parent banks (Ferreira et al. 2018). For pure asset managers, 401(k) plan assets are an important source of revenue that provides a strong incentive to not alienate corporate management. For the Big Three, the proportion of U.S. client assets coming from 401(k) plans in 2017 ranged from 14 to 20 percent (Bebchuk \& Hirst 2019: 2062). Proxy voting data shows that the largest asset managers overwhelmingly vote with management, especially on controversial issues (Heath et al. 2021). Out of almost 4000 shareholder proposals submitted to companies in the Russell 3000 index between 2008 and 2017, not a single one came from one of the Big Three (Bebchuk, Cohen \& Hirst 2017: 48).

As the Big Three have grown in size and (potential) power, regulators across the world have become increasingly concerned by their lack of monitoring and engagement. The global diffusion of so-called 'stewardship codes' (Hill 2017) should be seen in that light - as an attempt to ward off more heavy-handed forms of regulatory intervention. By signing on to stewardship codes, asset managers commit, for instance, to voting their shares and to making (aggregate) disclosures about their engagements with individual portfolio firms. Whereas stewardship codes aim at getting asset managers more involved in corporate governance, other policy proposals focus on "disintermediating" voting by giving asset owners (such as pension funds), or even ultimate beneficiaries (individual savers), the right to decide how their shares should be voted (Griffin 2020).

\footnotetext{
${ }^{19}$ Note that asset managers' stewardship teams remain far too small to monitor thousands of portfolio companies: the ratios of stewardship personnel to portfolio companies worldwide are 45/11,246 for BlackRock, 21/13,225 for Vanguard, and 12/12,191 for SSGA (Bebchuk \& Hirst 2019: 2077).
} 


\section{Sector level: Common ownership}

The concentration of corporate ownership among a small number of very large asset managers gives rise to the phenomenon of "common ownership" (Elhauge 2016; Azar et al. 2018; Backus, Conlon \& Sinkinson 2020). If all major firms in a given sector have the same (large) shareholders, the theory goes, shareholder returns are maximized if these firms engage in monopolistic pricing. The agenda-setting study on the anticompetitive effects of common ownership in the airline industry highlighted four potential causal mechanisms: "voice, incentives, and vote - as well as doing nothing, that is, simply not pushing for more aggressive competition" (Azar, Schmalz \& Tecu 2018: 1557). The potential implications are grave. From an "antitrust as allocator of coordination rights" perspective, by allowing common ownership, antitrust rules grant the largest asset managers coordination power unavailable to any other actors in the economy (Paul 2020). In the extreme case of all shareholders being fully diversified, shareholder value maximization implies "an economy-wide monopoly" (Azar 2020: $275)$.

The theory that common ownership has anti-competitive effects has rapidly gained traction among national (Federal Trade FTC 2018) and international (OECD 2017) policymakers. The stakes are extremely high for the asset management sector, which has contested the underlying research, while opposing regulatory initiatives (Fox 2019). Policy proposals are necessarily radical. One group of authors has suggested enforcing $\S 7$ of the 1914 Clayton Act, which would prohibit asset managers from owning more than one percent in more than a single firm in oligopolistic industries (Posner et al. 2017).

\section{Macro level I: Capital-labor split}

At the macro-level, the key question from a political economy perspective concerns the distributive consequences of asset manager capitalism. The shareholder primacy regime relentlessly pursued an agenda of strengthening the protection of (minority) shareholder rights while weakening the power of labor and pushing down wages (Hertel-Fernandez forthc.; Steinbaum 2021). The negative externalities - e.g., for 
public health or social cohesion - were not priced in by institutional investors with shareholdings in individual companies. Do universal owners price the social and economic costs of inequality differently?

Here, we encounter a fundamental problem with the promise of universal ownership. While asset managers are universal shareholders, the distribution of share ownership in society is extremely unequal. Figure 5 shows that the top 1 per cent of the wealth distribution own 50 per cent of the corporate equity and mutual fund shares (versus 35 per cent of total wealth), while the top 10 per cent own 86 per cent. This concentration of share ownership at the top counteracts the benign logic of universal ownership - shareholders may be fully diversified, but only half of the population own any shares at all. ${ }^{20}$ The test case for this argument are corporate strategies whose profits are outweighed by negative externalities that are, however, borne primarily by those who own few or no shares. Consider the example of worker pay. Wage stagnation for the bottom 50 per cent of the wealth distribution (those without shares) certainly has some negative externalities for the economy as a whole, notably in the form of lower aggregate demand. For shareholders, however, these externalities may be outweighed by higher corporate profits and thus higher returns. In other words, a negative externality for the poor can be a positive externality for the rich. Given the highly unequal distribution of shareholdings, even truly universal owners - such as the Big Three asset managers - should be expected to push the economy towards the lowest sustainable labor share.

Proposals to counter concentrated and coordinated shareholder power aim at reempowering workers. One way to achieve this is by wielding "labor's last best weapon", namely its pension funds (Webber 2018). However, pension fund activism has been fighting an uphill battle against existing rules and investment norms, which push them into the arms of asset managers (McCarthy et al. 2016). A different set of proposals

\footnotetext{
${ }^{20}$ Note that Figure 5 does not include retirement assets, which in 2018 stood at just over US 25 trillion, equivalent to roughly 50 per cent the market value of U.S. corporate equity. A large share of that capital is invested in stocks, via pension funds. Compared to direct equity and mutual fund holdings, the distribution of retirement assets is less skewed towards the top 1 per cent but still almost entirely passes by the bottom 50 per cent. Compared to other countries, U.S. households' financial assets account for a particularly large contribution to wealth inequality, relative to housing assets and non-housing real assets (Pfeffer \& Waitkus 2020: 26-28).
} 
aim at strengthening the power of workers in the boardroom, either through a Germanstyle system of "codetermination" (Palladino 2019) or through full-blown "economic bicamerialism" (Ferreras 2017).

Figure 5: Equity and mutual fund holdings by wealth group, 1989-2020

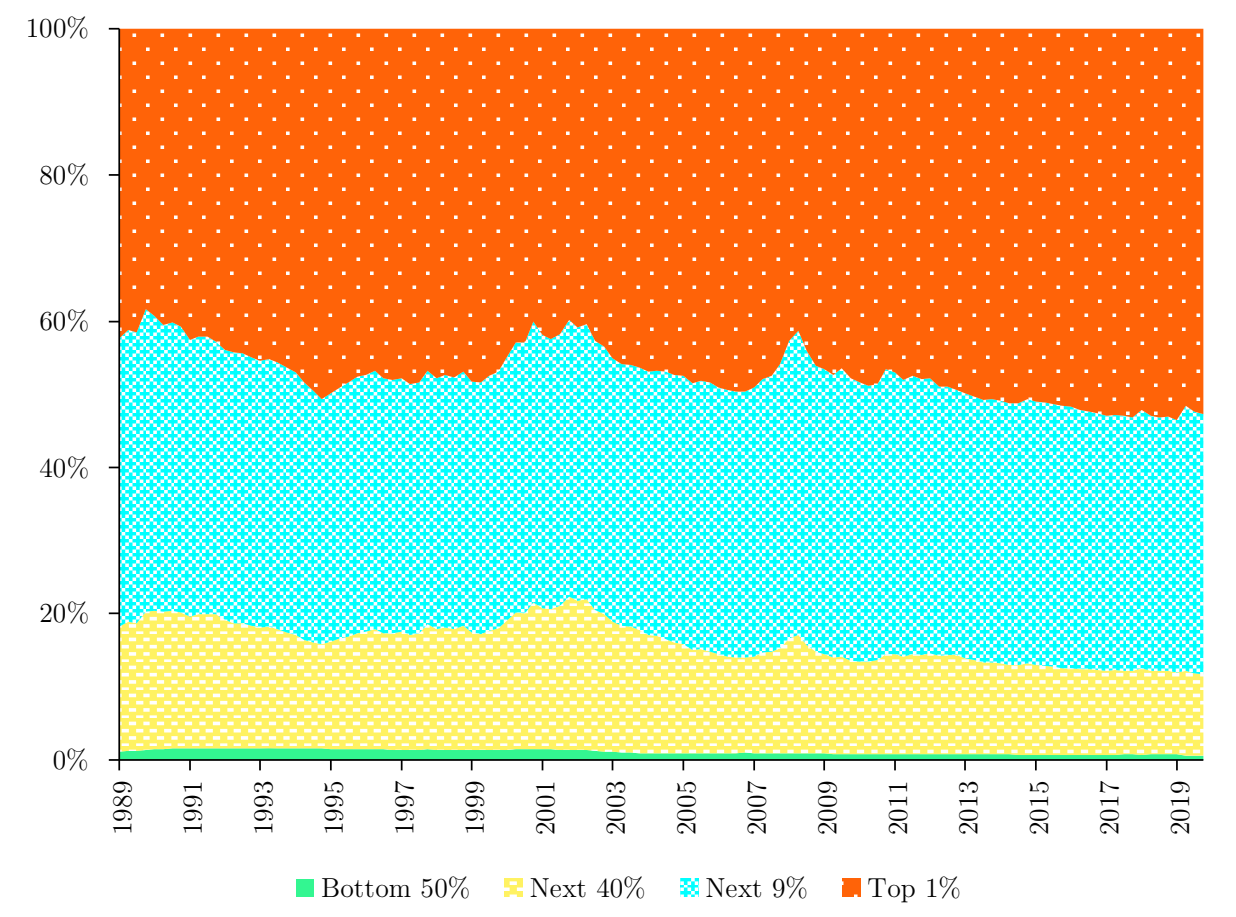

Source: Federal Reserve, U.S. distributional financial accounts.

\section{Macro-level II: The politics of asset price inflation}

The business model of BlackRock is geared towards maximizing (the value of) assets under management. While competition for existing savings is zero sum, government policy in general, and retirement policy in particular, determine how and how much people save. With retirement assets accounting for the biggest chunk of the asset management pie $-46 \%$ of U.S. mutual fund assets, see Figure 3 - asset managers have a strong vested interest in retirement policy (Naczyk 2013; 2018). The scope of this interest is global. When the Group of Thirty published a report on "Fixing the pension crisis", the six-member working group included representatives of BlackRock and UBS (Group of Thirty 2019). When protests erupted in France against President Macron's planned pension reforms, protesters targeted BlackRock, which had published a white paper in favor of pension privatization, and whose CEO had been photographed at the Élysée Palace (BlackRock 2019b; Alderman 2020). 
Whereas social policy can mobilize more of the base ingredient (savings), macroeconomic policy has the power to inflate the pie (asset prices). ${ }^{21}$ Since asset management fees are charged as a percentage of the current value of a client's assets, asset price inflation is a substitute for fund inflows. And other things equal, a fall of the interest rate increases asset prices. The implications for the political economy of monetary policy are substantial. The financial sector has long been treated as the most powerful 'hard money' constituency because inflation devalues banks' nominal claims against borrowers (Posen 1993). Asset managers, by contrast, fear a devaluation of their asset base more than inflation, making them a powerful 'easy money' constituency. BlackRock's deep ties with central banks across the world illustrate the point. The Federal Reserve has hired BlackRock to manage distressed asset portfolios and conduct corporate bond purchases, and BlackRock has performed similar services for the central banks of Canada, the euro area, and Sweden. This role as conduit for unconventional monetary policy implementation affords BlackRock considerable "infrastructural power" vis-à-vis state policymakers (Braun 2020). In order to wield that power effectively, BlackRock has hired former senior central bankers, including Philipp Hildebrand (former chairman of the Swiss National Bank, hired in 2012), Jean Boivin (deputy governor of the Bank of Canada, 2014), and Stanley Fischer (vicechairman of the Fed, 2019). In August 2019, this trio presented a paper titled "Dealing with the next downturn" at the Fed's annual Jackson Hole symposium that called for audacious monetary easing in the next crisis. The paper urged central banks to "go direct" by getting "central bank money directly in the hands of public and private sector spenders" while seeking explicit coordination with fiscal policy in order to prevent interest rates from rising (BlackRock Investment Institute 2019: 2). "Going direct" was indeed what the Fed did in response to the Covid-19 crisis, illustrating BlackRock's transition from being a monetary policy taker to acting as a monetary policy maker..$^{22}$

\footnotetext{
${ }^{21}$ Aggregate stock market valuations can also be increased through the corporate governance process. Diversified asset managers calling on pharma companies to adopt a cooperative approach to developing a Covid-19 vaccine instead of maximizing profits from individual patents - can be understood in this manner (Levine 2020).

${ }^{22}$ Another policy area in which asset managers exercise outsize influence is development finance (Gabor 2021).
} 


\section{Conclusion}

At first blush, the new shareholder structure resembles that of the late $19^{\text {th }}$ century: the equity of a concentrated corporate sector is concentrated in the hands of only a handful of financial firms. Two features, however, distinguish the new asset manager capitalism from finance capitalism. First, unlike their robber baron predecessors, today's dominant owners are fully diversified. Second, asset managers are economically disinterested intermediaries - they lack skin in the corporate game. Unlike robber barons, their business model is to compete for capital and management fees from investors. The returns from their shareholdings matter in this competition, but asset managers only own the legal title, not the economic interest in the corporations whose stock they hold. At closer inspection, asset manager capitalism is without historical precedent.

Moving beyond the BM-JM ontology opens up promising avenues for research on the political economy of asset manager capitalism and corporate governance. The first relates to the stakeholder coalition perspective that has dominated the CPE literature on corporate governance (Aguilera \& Jackson 2003; Höpner 2003; Gourevitch \& Shinn 2005). This literature has interpreted the shareholder primacy regime in LMEs as an alliance of shareholders and workers - embodied in powerful public pension funds - against corporate managers. Like other aspects of the CPE literature, this interpretation reflected early-1990s pension fund capitalism but was largely obsolete by the early 2000s, when shareholders had closed ranks with managers, in terms of both ideology and class (Boyer 2005; Duménil \& Lévy 2011; Goldstein 2012). However, these accounts still conceptualize shareholders as owners. As the discussion of the incentives of today's asset management conglomerates shows, what has come to pass is an alliance between managers and asset managers. Unprecedented shareholder power coexists with a corporate governance world of 'managers all the way down'. One potential consequence of the disinterested nature of large diversified asset managers is the empowerment corporate managers, at the expense of shareholders. Equally plausible, however, is the argument that power shifts to other types of shareholders (Deeg \& Hardie 2016). For instance, the initiative for engagements with individual companies now often comes from activist hedge funds that then seek the support of 
the Big Three (Aguilera et al. 2019). Another empowered shareholder category are sovereign wealth funds, the largest of which are also universal owners but without some of the business-model related conflicts of interest (Babic et al. 2020). Mapping the new distribution of power between these various actors calls for close examination of increasingly complex investment chain dynamics.

Secondly, my analysis challenges the view, widespread in CPE, that stock ownership patterns and corporate governance regimes are stable, rooted in national institutional and ideological legacies. As one proponent of this view has noted, corporate governance "is partly just the tail to the larger kite of the organization of savings" - that is, of the investment chain (Roe 1994: xv). However, whereas in Roe's theory the investment chain is shaped by policies conditioned by history and political ideology - in the U.S. case: mistrust of concentrated financial power - this paper shows that the investment chain is also the tail to the larger kites of capitalist accumulation, wealth inequality, and financialization. Fostering private wealth accumulation - a U.S. policy priority for the last seven decades - and restricting concentrated financial power in the asset management sector are likely two inconsistent policy goals. The ease with which the latter goal has recently been abandoned supports the view that the investment chain is, in fact, prone to dramatic regime shifts. Moreover, in a globalized financial system, the investment chain in any individual country - and thus its corporate governance regime - is also a function of the organization and regulation of savings in the rest of the world (Oatley \& Petrova 2020). This holds both ways - 40 per cent of BlackRock's assets are managed for clients outside of the United States (BlackRock 2019a: 1), while BlackRock is also a shareholder in thousands of non-U.S. firms across the globe. Asset manager capitalism is a global regime. 


\section{References}

Adkins, Lisa, Melinda Cooper, and Martijn Konings. 2020. The Asset Economy. Cambridge: Polity.

Aglietta, Michel. 1979. A theory of capitalist regulation: The US experience. London: Verso.

Aguilera, Ruth V., Ryan Federo, and Yuliya Ponomareva. 2019. "Gone Global: The International Diffusion of Hedge Fund Activism Outside the United States." Available at SSRN 3402966.

Aguilera, Ruth V., and Gregory Jackson. 2003. "The Cross-National Diversity of Corporate Governance: Dimensions and Determinants." The Academy of Management Review 28 (3): 447-65.

Ajdacic, Lena, Eelke M. Heemskerk, and Javier Garcia-Bernardo. 2020. "The Wealth Defence Industry: A Large-scale Study on Accountancy Firms as Profit Shifting Facilitators." New Political Economy: 1-17. doi:10.1080/13563467.2020.1816947.

Alderman, Liz. 2020. "BlackRock Becomes a Symbol for Anticapitalist Fervor in France." New York Times, February 14. Accessed 05/15/2020. https://www.nytimes.com/2020/02/14/business/franceblackrock-protests.html.

Ansell, Ben. 2012. "Assets in Crisis: Housing, Preferences and Policy in the Credit Crisis." Swiss Political Science Review 18 (4): 531-37. doi:doi:10.1111/spsr.12013.

Ansell, Ben, and Jane Gingrich. forthc. "Concentration and Commodification: The Political Economy of Postindustrialism in America and Beyond." In American political economy, edited by Jacob Hacker, Alexander Hertel-Fernandez, Paul Pierson and Kathleen Thelen.

Arjaliès, Diane-Laure, Philip Grant, Iain Hardie, Donald MacKenzie, and Ekaterina Svetlova. 2017. Chains of finance: How investment management is shaped. Oxford: Oxford University Press.

Azar, José. 2020. "The Common Ownership Trilemma." The University of Chicago Law Review 87 (2): 263-96.

Azar, José, Miguel Duro, Igor Kadach, and Gaizka Ormazabal. 2020. "The Big Three and Corporate Carbon Emissions Around the World." Available at SSRN 3553258.

Azar, José, Martin C Schmalz, and Isabel Tecu. 2018. "Anticompetitive Effects of Common Ownership." The Journal of Finance 73 (4): 1513-65. doi:doi:10.1111/jofi.12698.

Babic, Milan, Javier Garcia-Bernardo, and Eelke M. Heemskerk. 2020. "The rise of transnational state capital: state-led foreign investment in the 21st century." Review of International Political Economy 27 (3): 433-75. doi:10.1080/09692290.2019.1665084.

Backus, Matthew, Christopher Conlon, and Michael Sinkinson. 2020. "Common Ownership in America: 1980-2017." American Economic Journal: Microeconomics Advance Online Publication.

Baran, Paul A., and Paul M. Sweezy. 1966. Monopoly capital. New York: NYU Press.

Bebchuk, Lucian A., Alma Cohen, and Scott Hirst. 2017. "The agency problems of institutional investors." Journal of Economic Perspectives 31 (3): 89-102.

Bebchuk, Lucian A., and Scott Hirst. 2019. "Index Funds and the Future of Corporate Governance: Theory, Evidence, and Policy." Columbia Law Review 119 (8): 2029-145.

Berle, Adolf A., and Gardiner C. Means. 1932. The modern corporation and private property. New York: Macmillan.

BlackRock. 2019a. "Annual Report 2018." Accessed 02/05/2020. https://s24.q4cdn.com/856567660/files/doc_financials/2018/ar/2018-Annual-Report.pdf.

BlackRock. 2019b. "Loi Pacte: Le bon plan Retraite." Accessed 05/15/2020. https://www.blackrock.com/corporate/literature/whitepaper/viewpoint-loi-pacte-le-bon-plan-retraitejuin-2019.pdf.

Bogle, John C. 2012. The clash of the cultures: Investment vs. speculation. John Wiley \& Sons. 
Boyer, Robert. 2000. "Is a finance-led growth regime a viable alternative to Fordism? A preliminary analysis." Economy and Society 29 (1): 111-45.

Boyer, Robert. 2005. "From Shareholder Value to CEO Power: The Paradox of the 1990s." Competition \&6 Change 9 (1): 7-47. doi:10.1179/102452905X38623.

Braun, Benjamin. 2016. "From performativity to political economy: index investing, ETFs and asset manager capitalism." New Political Economy 21 (3): 257-73. doi:10.1080/13563467.2016.1094045.

Braun, Benjamin. 2020. "Central banking and the infrastructural power of finance: The case of ECB support for repo and securitization markets." Socio-Economic Review 18 (2): 395-418.

Briere, Marie, Sebastien Pouget, and Loredana Ureche. 2019. Do universal owners vote to curb negative corporate externalities? An empirical analysis of shareholder meetings. Available at SSRN: 3140043.

Chandler, Alfred D. 1977. The visible hand. The Managerial Revolution in American Business. Cambridge, MA: Harvard University Press.

Christophers, Brett. 2019. "Environmental beta or how institutional investors think about climate change and fossil fuel risk." Annals of the American Association of Geographers 109 (3): 754-74.

Christophers, Brett. 2020. Rentier Capitalism: Who Owns the Economy, and Who Pays for It? London: Verso.

Chwieroth, Jeffrey M., and Andrew Walter. 2019. The Wealth Effect: How the Great Expectations of the Middle Class Have Changed the Politics of Banking Crises. Cambridge: Cambridge University Press.

Ciepley, David. 2013. "Beyond Public and Private: Toward a Political Theory of the Corporation." American Political Science Review 107 (01): 139-58. doi:10.1017/S0003055412000536.

Clark, Gordon L. 2000. Pension fund capitalism. Oxford: Oxford University Press.

Clark, Gordon L., and Ashby H.B. Monk. 2017. Institutional investors in global markets. Oxford: Oxford University Press.

Clowes, Michael J. 2000. The money flood: how pension funds revolutionized investing. Wiley.

Coates, John C., IV. 2009. "Reforming the Taxation and Regulation of Mutual Funds: A Comparative Legal and Economic Analysis." Journal of Legal Analysis 1 (2): 591-689.

Coffee, John C. Jr. 1991. "Liquidity versus Control: The Institutional Investor as Corporate Monitor." Columbia Law Review 91 (6): 1277-368.

Condon, Madison. 2020. "Externalities and the Common Owner." Washington Law Review 95 (1-81).

Crouch, Colin. 2009. "Privatised Keynesianism: An unacknowledged policy regime." British Journal of Politics $\mathcal{G}_{3}$ International Relations 11 (3): 382-99. doi:10.1111/j.1467-856X.2009.00377.x.

Culpepper, Pepper D. 2005. "Institutional Change in Contemporary Capitalism: Coordinated Financial Systems since 1990." World Politics 57 (2): 173-99.

Davis, Gerald F. 2008. "A new finance capitalism? Mutual funds and ownership re-concentration in the United States." European Management Review 5 (1): 11-21.

Davis, Gerald F., and Tracy A. Thompson. 1994. "A social movement perspective on corporate control." Administrative Science Quarterly 39 (1): 141-73.

Deeg, Richard, and Iain Hardie. 2016. "What is patient capital and who supplies it?" Socio-Economic Review 14 (4): 627-45.

Dixon, Adam D. 2012. "Function before form: macro-institutional comparison and the geography of finance." Journal of Economic Geography 12 (3): 579-600.

Drucker, Peter F. 1976. The unseen revolution: How pension fund socialism came to America. New York: Harper \& Row.

Duménil, Gérard, and Dominique Lévy. 2011. The crisis of neoliberalism. Harvard University Press.

Elhauge, Einer. 2016. "Horizontal Shareholding." Harvard Law Review 129: 1267-317. 
Fama, Eugene F., and Michael C. Jensen. 1983. "Separation of ownership and control." The Journal of Law and Economics 26 (2): 301-25.

Ferreira, Miguel A, Pedro Matos, and Pedro Pires. 2018. "Asset management within commercial banking groups: International evidence." The Journal of Finance 73 (5): 2181-227.

Ferreras, Isabelle. 2017. Firms as political entities: Saving democracy through economic bicameralism. Cambridge University Press.

Fichtner, Jan, and Eelke M. Heemskerk. 2020. "The new permanent universal owners: Index funds, patient capital, and the distinction between feeble and forceful stewardship." Economy and Society 49 (4): 493515 .

Fichtner, Jan, Eelke M. Heemskerk, and Javier Garcia-Bernardo. 2017. "Hidden power of the Big Three? Passive index funds, re-concentration of corporate ownership, and new financial risk." Business and Politics 19 (2): 298-326.

Fink, Matthew P. 2008. The rise of mutual funds: an insider's view. New York: Oxford University Press.

Fisch, Jill E., Assaf Hamdani, and Steven Davidoff Solomon. 2019. "The New Titans of Wall Street: A Theoretical Framework for Passive Investors." University of Pennsylvania Law Review 168: 17-72.

Flood, Chris. 2020. "The \$5tn club: Merger mania sweeps asset management industry." Financial Times, November 13. Accessed 12/13/2020. https://www.ft.com/content/d8e07916-a5ea-451f-acf235cd1be6639d.

Fourcade, Marion, and Rakesh Khurana. 2017. "The Social Trajectory of a Finance Professor and the Common Sense of Capital." History of Political Economy 49 (2): 347-81.

Fox, Brooke. 2019. "Asset managers fight to prevent limits on company ownership." Financial Times, February 14. Accessed 04/20/2019. https://www.ft.com/content/af19e6ca-2f02-11e9-ba00$0251022932 \mathrm{c} 8$.

Franks, Julian, Colin Mayer, and Stefano Rossi. 2008. "Ownership: Evolution and regulation." The Review of Financial Studies 22 (10): 4009-56.

Federal Trade Commission. 2018. FTC Hearing \#8: Common Ownership. Washington, DC. Accessed 04/20/2019. https://www.ftc.gov/policy/public-comments/2018/12/initiative-789.

Gabor, Daniela. 2021. "The Wall Street Consensus." Development and Change, Advance Online Publication.

Gilson, Ronald J., and Jeffrey N. Gordon. 2013. "The agency costs of agency capitalism: Activist investors and the revaluation of governance rights." Columbia Law Review 113 (4): 863-927.

Goldstein, Adam. 2012. "Revenge of the managers: Labor cost-cutting and the paradoxical resurgence of managerialism in the shareholder value era, 1984 to 2001." American Sociological Review 77 (2): 26894 .

Gourevitch, Peter A., and James Shinn. 2005. Political power and corporate control: The new global politics of corporate governance. Princeton, NJ: Princeton University Press.

Goyer, Michel. 2011. Contingent capital: Short-term investors and the evolution of corporate governance in France and Germany. Oxford: Oxford University Press.

Greenwood, Robin, and David Scharfstein. 2013. "The growth of finance." The Journal of Economic Perspectives 27 (2): 3-28.

Griffin, Caleb N. 2020. "We Three Kings: Disintermediating Voting at the Index Fund Giants." Maryland Law Review 79 (4): 954-1008.

Haberly, Daniel, Duncan MacDonald-Korth, Michael Urban, and Dariusz Wójcik. 2019. "Asset management as a digital platform industry: A global financial network perspective." Geoforum 106: 16781. 
Hacker, Jacob S. 2019. The great risk shift: The new economic insecurity and the decline of the American dream. 2nd ed. New York: Oxford University Press.

Hall, Peter A., and David Soskice. 2001. "An Introduction to Varieties of Capitalism." In Varieties of Capitalism. The Institutional Foundations of Comparative Advantage, edited by Peter A. Hall and David Soskice, 1-68. Oxford: Oxford University Press.

Hansmann, Henry, and Reinier Kraakman. 2001. "The End of History for Corporate Law." Georgetown Law Journal 89: 439-68.

Hawley, James P., and Andrew T. Williams. 2000. The rise of fiduciary capitalism: How institutional investors can make corporate America more democratic. University of Pennsylvania Press.

Heath, Davidson, Daniele Macciocchi, Roni Michaely, and Matthew Ringgenberg. 2021. "Do Index Funds Monitor?" Review of Financial Studies.

Hertel-Fernandez, Alexander. forthc. "Collective Action and the Past and Future Development of the American Labor Movement." In American Political Economy: Politics, Markets, and Power, edited by Jacob Hacker, Alexander Hertel-Fernandez, Paul Pierson and Kathleen Thelen.

Hilferding, Rudolf. 1985 [1910]. Finance capital: a study of the latest phase of capitalist development. Routledge.

Hill, Jennifer G. 2017. "Good Activist/Bad Activist: The Rise of International Stewardship Codes." Seattle University Law Review 41: 497-524.

Höpner, Martin. 2003. Wer beherrscht die Unternehmen? Shareholder Value, Managerherrschaft und Mitbestimmung in Deutschland. Campus Verlag.

BlackRock Investment Institute. 2019. Dealing with the next downturn: From unconventional monetary policy to unprecedented policy coordination.

Jahnke, Patrick. 2019. "Ownership concentration and institutional investors' governance through voice and exit." Business and Politics 21 (3): 327-50.

Jensen, Michael C., and William H. Meckling. 1976. "Theory of the firm: Managerial behavior, agency costs and ownership structure." Journal of Financial Economics 3 (4): 305-60.

Kay, John. 2012. The Kay Review of UK Equity Markets and Long-Term Decision Making. Review commissioned by the Secretary of State for Business, Innovation and Skills

Kim, Crystal. 2019. "The ETF Business Is Dominated by the Big Three. The SEC Is Suddenly Concerned." Barron's, 5 April. Accessed 04/15/2019. ㄴttps://www.barrons.com/articles/etfs-are-dominatedby-blackrock-vanguard-and-state-street-the-sec-is-concerned-51554512133.

Knafo, Samuel, and Sahil Jai Dutta. 2020. "The myth of the shareholder revolution and the financialization of the firm." Review of International Political Economy 27 (3): 476-99.

Kotz, David M., Terrence McDonough, and Michael Reich, eds. 1994. Social structures of accumulation: The political economy of growth and crisis. Cambridge: Cambridge University Press.

La Porta, Rafael, Florencio Lopez-de-Silanes, Andrei Shleifer, and Robert Vishny. 2000. "Investor protection and corporate governance." Journal of Financial Economics 58 (1): 3-27.

Lazonick, William, and Mary O'Sullivan. 2000. "Maximizing shareholder value: a new ideology for corporate governance." Economy and Society 29 (1): 13-35.

Levine, Matt. 2020. "Investors Want a Cure, Not a Winner." Bloomberg, April 24. Accessed 06/01/2020. https://www.bloomberg.com/opinion/articles/2020-04-24/investors-want-a-cure-not-a-winner.

Lund, Dorothy S. 2017. "The case against passive shareholder voting." Journal of Corporation Law 43: 493-536.

Marx, Karl. 1981[1894]. Capital, Volume 3. London: Penguin.

McCarthy, Michael A. 2017. Dismantling Solidarity: Capitalist Politics and American Pensions Since the New Deal. Ithaca, NY: Cornell University Press. 
McCarthy, Michael A., Ville-Pekka Sorsa, and Natascha van der Zwan. 2016. "Investment preferences and patient capital: financing, governance, and regulation in pension fund capitalism." Socio-Economic Review 14 (4): 751-69.

Monks, Robert A. G., and Nell Minow. 1995. Corporate Governance. Malden, MA: Basil Blackwell.

Montagne, Sabine. 2013. "Investing prudently: How financialization puts a legal standard to use." Sociologie du Travail 55 (Supplement 1): 48-66.

Mooney, Attracta, and Donato Paolo Mancini. 2020. "Drugmakers urged to collaborate on coronavirus vaccine." Financial Times, April 24. Accessed 06/01/2020. https://www.ft.com/content/b452ceb9-765a4c25-9876-fb73d736f92a.

Mooney, Attracta, and Peter Smith. 2019. "Larry Fink, Barclays and the deal of the decade." Financial Times, May 6. Accessed 02/05/2020. https://www.ft.com/content/48e703d8-6d87-11e9-80c760ee53e6681d.

Naczyk, Marek. 2013. "Agents of privatization? Business groups and the rise of pension funds in Continental Europe." Socio-Economic Review 11 (3): 441-69.

Naczyk, Marek. 2018. "When finance captures labor's capital: Dominant personal pensions, resurgent occupational provision in Central and Eastern Europe." Social Policy 83 Administration 52 (2): 549-62.

Naidu, Suresh. forthc. "American labor politics via labor market power." In American Political Economy: Politics, Markets, and Power, edited by Jacob Hacker, Alexander Hertel-Fernandez, Paul Pierson and Kathleen Thelen.

Oatley, Thomas, and Bilyana Petrova. 2020. "The global deregulation hypothesis." Socio-Economic Review.

OECD. 2017. Hearing on Common ownership by institutional investors and its impact on competition Summaries of Contributions. Accessed 04/20/2019. http://www.oecd.org/competition/commonownership-and-its-impact-on-competition.htm.

Ott, Julia C. 2011. When Wall Street Met Main Street. Cambridge, MA: Harvard University Press.

Palladino, Lenore. 2019. Worker Representation on U.S. Corporate Boards. Available at http://dx.doi.org/10.2139/ssrn.3476669.

Paul, Sanjukta. 2020. "Antitrust as Allocator of Coordination Rights." UCLA Law Review 67 (2): 1-64.

Petry, Johannes. 2020. "From National Marketplaces to Global Providers of Financial Infrastructures: Exchanges, Infrastructures and Structural Power in Global Finance." New Political Economy: 1-24.

Petry, Johannes, Jan Fichtner, and Eelke Heemskerk. 2021. "Steering capital: the growing private authority of index providers in the age of passive asset management." Review of International Political Economy 28 (1): 152-76.

Pfeffer, Fabian, and Nora Waitkus. 2020. Wealth inequality of nations. LWS Working Paper no. 33. Luxembourg: Luxembourg Income Study.

Philippon, Thomas. 2019. The Great Reversal: How America Gave Up on Free Markets. Cambridge, MA: Harvard University Press.

Posen, Adam S. 1993. "Why central bank independence does not cause low inflation: there is no institutional fix for politics." In Finance and the International Economy: 7, The AMEX Bank Review Prize Essays, edited by Richard O'Brien, 41-65. Oxford: Oxford University Press.

Posner, Eric A., Fiona M. Scott Morton, and E. Glen Weyl. 2017. "A proposal to limit the anti-competitive power of institutional investors." Antitrust Law Journal 81 (3): 669-728.

Poterba, James M, and John B Shoven. 2002. "Exchange-traded funds: A new investment option for taxable investors." American Economic Review 92 (2): 422-27.

Rahman, Sabeel K., and Kathleen Thelen. 2019. "The Rise of the Platform Business Model and the Transformation of Twenty-First-Century Capitalism." Politics 83 Society 47 (2): 177-204. 
Rahman, Sabeel K., and Kathleen Thelen. forthc. "The Role of the Law in the American Political Economy." In American Political Economy: Politics, Markets, and Power, edited by Jacob Hacker, Alexander Hertel-Fernandez, Paul Pierson and Kathleen Thelen.

Riding, Siobhan. 2020. "Trillion-dollar club tightens grip on fund market during crisis." Financial Times, May 10. Accessed 05/14/2020. https://www.ft.com/content/a6aa1010-3dff-4521-af52-fbadb496c89d.

Ringe, Wolf-Georg. 2016. The deconstruction of equity: activist shareholders, decoupled risk, and corporate governance. Oxford: Oxford University Press.

Roe, Mark J. 1994. Strong Managers, Weak Owners. The Political Roots of American Corporate Finance. Princeton, NJ: Princeton University Press.

Schwartz, Herman Mark. 2017. "Club goods, intellectual property rights, and profitability in the information economy." Business and Politics 19 (2): 191-214. doi:10.1017/bap.2016.11.

Schwartz, Herman Mark. forthc. "Mo' patents, mo' problems: Corporate strategy, structure and profitability in America's political economy." In American Political Economy: Politics, Markets, and Power, edited by Jacob Hacker, Alexander Hertel-Fernandez, Paul Pierson and Kathleen Thelen.

SEC. 2019. Release No. 33-10695 on Exchange-Traded Funds. Securities and Exchange Commission. Accessed 05/02/2020. https://www.sec.gov/rules/final/2019/33-10695.pdf.

Srnicek, Nick. 2017. Platform capitalism. Cambridge: Polity.

Steinbaum, Marshall. 2021. "Common Ownership and the Corporate Governance Channel for Employer Power in Labor Markets." Antitrust Bulletin 66(1):123-39.

Stout, Lynn A. 2012. The shareholder value myth: How putting shareholders first harms investors, corporations, and the public. San Francisco, CA: Berrett-Koehler Publishers.

Strine Jr, Leo E. 2007. "Toward common sense and common ground-reflections on the shared interests of managers and labor in a more rational system of corporate governance." The Journal of Corporation Law 33 (1): 1-20.

Group of Thirty. 2019. Fixing the pension crisis: Ensuring Lifetime Financial Security. Washington, DC. Accessed 05/15/2020. https://group30.org/images/uploads/publications/G30 Pensions.pdf.

Useem, Michael. 1996. Investor capitalism: How money managers are changing the face of corporate America. Basic Books.

van der Zwan, Natascha. 2017. "Financialisation and the pension system: Lessons from the United States and the Netherlands." Journal of Modern European History 15 (4): 554-84.

Veblen, Thorstein. 1923. Absentee Ownership: Business Enterprise in Recent Times-The Case of America. New York: B.W. Huebsch.

Webber, David. 2018. The rise of the working-class shareholder: Labor's last best weapon. Cambridge, MA: Harvard University Press.

Weil, David. 2014. The fissured workplace. Cambridge, MA: Harvard University Press.

Windolf, Paul, and Jürgen Beyer. 1996. "Co-operative capitalism: corporate networks in Germany and Britain." British Journal of Sociology: 205-31.

Winters, Jeffrey A. 2017. "Wealth defense and the complicity of liberal democracy." NOMOS LVIII: Wealth: 158-225.

Wooten, James. 2004. The Employee Retirement Income Security Act of 1974: A Political History. Vol. 11 of. Berkeley, CA: University of California Press.

Zetzsche, Dirk A., William A. Birdthistle, Douglas W. Arner, and Ross P. Buckley. 2020 "Digital Finance Platforms: Toward a New Regulatory Paradigm." University of Pennsylvania Journal of Business Law 23(1):273-339. 